\title{
MOTIVASI MASYARAKAT INDONESIA MENJADI TENAGA KERJA INDONESIA (STUDI KASUS PADA MASYARAKAT KECAMATAN PANCENG KABUPATEN GRESIK)
}

\author{
Maulidyah Amalina Rizqi, Wasti Reviandani \\ maulidyah@umg.ac.id. \\ Program Studi Manajemen Fakultas Ekonomi dan Bisnis \\ Universitas Muhammadiyah Gresik
}

\begin{abstract}
The number of unemployed continue to rise, people can not afford to make business that is caused by bumped capital, skills, and limited market access. In fact, positive benefits for migrant workers who work abroad are also many to get jobs, income, improve welfare and develop skills. This research uses descriptive qualitative method by making the migrant workers and former migrant workers as key informant as well as to extract the data through 3 kinds of way, interview, observation and documentation. From this research, there are many factors that influence the people of Gresik Regency to become migrant workers such as, at least the employment around them, the low level of education, the economic factor of the family, and the environment, whether from the internal family and the environment. Another thing that gained from this research is still many people who become TKI with illegal status.
\end{abstract}

Keywords: Indonesian workforce (TKI), Society Indonesia

\section{PENDAHULUAN}

Sempitnya lapangan pekerjaan menjadikan Jumlah pengangguran terus meningkat, masyarakat tidak mampu untuk membuat usaha yang disebabkan dengan terbentur modal, ketrampilan, dan terbatas akses pasar.
Apabila peluang kerja semakin sempit maka permasalahan kehidupan masyarakat akan bertambah. Namun, mereka tidak tinggal diam, mereka berusaha untuk memecahkan masalah mereka dengan memilih menjadi TKI (Tenaga 
Kerja Indonesia) sebagai solusi tercepat.

Dampak-dampak positif maupun negatif dari menjadi TKI di luar negeri telah diketahui masyarakat luas tetapi hal tersebut tidak menyurutkan keinginan mereka untuk tetap menjadi TKI. Karena sesungguhnya mereka ingin mendapatkan penghasilan yang lebih besar meski tingkat pendididikan mereka rendah. Banyak dari TKI tersebut yang hanya memiliki pendidikan lulusan SD (sekolah dasar/ Madrasah Ibtidaiyah) ataupun SMP (Sekolah Menengah Pertama) bahkan tidak sedikit dari mereka yang lulusan SMA (Sekolah Menengah Atas).

Dengan memiliki modal keterampilan dan pendidikan terbatas mereka akan mendapatkan penghasilan tinggi tanpa menghiraukan dampak negatif yang mungkin akan terjadi. Meski hakikatnya dampak negatif yang mungkin dapat mereka alami lebih besar daripada dampak positif akan mereka hadapi nantinya.

Fenomena inilah yang membuat peneliti untuk melakukan penelitian dan menggali informasi lebih mendalam kepada masyarakat Indonesia khususnya terfokus pada masyarakat Kecamatan
Panceng Kabupaten Gresik (Utara). Peneliti bertujuan untuk mengungkap faktor apa yang memotivasi masyarakat Kecamatan Panceng Kabupaten Gresik untuk menjadi TKI di Luar Negeri selain faktor ekonomi (finansial).

\section{KAJIAN PUSTAKA}

\section{Motivasi}

Motivasi adalah "prosesproses psikologis yang menyebabkan Stimulasi, arahan, dan kegigihan akan sebuah kegiatan yang dilakukan secara sukarela yang diarahkan pada suatu tujuan" (Robert Kreitner, 2014). Hampir semua Teori Motivasi mengemukakan keterkaitan Motivasi dengan kebutuhankebutuhan manusia. Dengan memenuhi kebutuhan manusia tersebut, Motivasi kerja secara otomatis akan terwujud. Jika motivasi kerja terwujud maka kebutuhan dan keinginan manusia dapat terpenuhi. Karena itu motivasi kerja dapat diartikan sebagai bagian integral dari hubungan/ industrial dalam rangka proses pembinaan, pengembangan, dan pengarahan sumber daya manusia dalam suatu perusahaan (Sinungan, 2008) 


\section{TKI (Tenaga Kerja Indonesia)}

Tenaga kerja Indonesia atau sering kita sebut dengan TKI adalah tiap orang yang yang mampu melakukan pekerjaan baik didalam maupun di luar hubungan kerja guna menghasilkan barang atau jasa untuk memenuhi kebutuhan hidupnya. Dari definisi tersebut dapat kita ambil kesimpulan bahwa yang dimaksud dengan tenaga kerja Indonesia (TKI) adalah individu yang mampu bekerja dalam rangka menghasilkan jasa guna untuk memenuhi kebutuhan hidupnya.

Kemudian dengan istilah tenga kerja Indonesia (TKI) yang berasal dari istilah tenaga kerja, kemudian diberi tambahan belakang dengan kalimat Indonesia yang menunjukkan kata arti khusus yaitu tenaga kerja Indonesia. Namun istilah TKI yang sering kita dengar dan yang dimaksud disini adalah TKI yang mempunyai arti sendiri yaitu merupakan jabatan atau predikat seseorang yang dipekerjakan diluar negeri.

Macam-Macam Tenaga Kerja Indonesia (TKI)

Tenaga kerja Indonesia ada dua macam:

1) Tenaga kerja Legal
Tenaga kerja Indonesia adalah warga negara Indonesia yang melakukan kegiatan sosial ekonomi di luar negeri dalam jangka waktu yang tertentu serta memperoleh izin atau pengesahan dari pemerintah yang menangani masalah TKI. Pemerintah telah mengatur dalam proses pemberangkatan tenaga kerja Indonesia keluar negeri harus memenuhi beberapa syarat salah satunya usia dan kartu tanda penduduk (KTP).

2) Tenaga kerja Ilegal

Proses pemberangkatan tenaga kerja Indonesia ke luar negeri telah diatur dengan tertib oleh pemerintah yang ditangani langsung oleh DEPNAKER yang tentunya sangat prosedural dan tertib segala sesuatu terkait administrasi antara lain mulai dari persyaratan yang harus dipenuhi sebelum berangkat ke luar negeri, pendidikan dan pelatihan kerja sebagai persiapan sebelum sampai di negara lain supaya menjadi TKI betul-betul profesional, sampai peraturan tenaga kerja setelah sampai di sana. Rupanya prosedur diatas bagi masyarakat 
pedesaan sekarang dari semua yang peraturan yang ditetapkan oleh

DEPNAKER itu, dianggap terlalu sulit bagi mereka, karena berasumsi berapapun biaya transportasinya bahkan dua kali lipat tidak menjadi permasalahan yang terpenting mereka tidak dipersulit dan satu hal yang esensial mereka tidak ingin menunggu lama, kronologis semacam inilah yang menyebabkan para TKI lebih memilih ikut tekong dari pada mengikuti program DEPNAKER walaupun biaya transportasi lebih murah.

\section{METODE}

Penelitian ini merupakan penelitian deskriptif dengan metode kualitatif. Adapun jenis penelitian ini merupakan penelitian studi kasus dengan menggunakan desain kasus tunggal holistic, desain ini untuk melakukan eksplorasi secara mendalam (spesifik) tentang kejadian tertentu atau beberapa peristiwa dari sebuah fenomena. Penelitian ini hanya terfokus pada faktor yang mempengaruhi masyakat Kecamatan Panceng untuk menjadi TKI. Informan dalam penelitian ini adalah para
Tenaga Kerja Indonesia (TKI) yang masih aktif maupun yang sudah pensiun (mantan TKI). Teknik pengambilan data dalam penelitian ini menggunakan 3 metode yaitu dengan cara wawancara, observasi serta dokumentasi guna memperkuat hasil pengambilan datanya. Guna menjaga keabsahan data dalam penelitian, maka digunakan pemeriksaan keabsahan data sebagai berikut: (1) derajat kepercayaan (credibility), (2) keteralihan (transferability), (3) kebergantungan (dependability), dan obyektivitas (confirmability).

\section{HASIL PEMBAHASAN}

DAN

Hasil dari penelitian ini sesungguhnya membuat pengetahuan kita bertambah untuk dunia ketenagakerjaan, karena banyak hal yang tidak nampak kasat mata. Bahkan hasil penelitian ini dapat membuat para pembaca tercengang. Para tenaga kerja Indonesia yang berada di luar negeri ternyata memiliki usia yang bervariasi, dapat dikatakan bahwa mereka berangkat untuk mengadu nasib di negara orang dari usia yang sangat muda. Para informan yang kami temui juga mengatakan hal yang 
sama, ada yang setelah SD ikut keluarga yang sudah lebih dahulu disana dan ada juga yang setelah lulus SMP baru berangkat menjadi TKI. Kebanyakan yang berangkat menjadi TKI hanya memiliki pendidikan setara SD (sekolah dasar) atau biasa mereka menyebutnya dengan sekolah madrasah. Alasan mereka tidak melanjutkan sekolah mereka adalah faktor biaya, dan memilih membantu orang tua mereka yang sudah lebih dahulu ada di luar negeri.

Faktor yang memotivasi mereka untuk menjadi TKI ada dua hal, yang pertama ajakan atau perintah dari keluarga dan yang kedua atas dasar inisiatif mereka sendiri dengan alasan ingin meningkatkan dan membantu perekonomian keluarga. Selain itu mereka memilih menjadi TKI karena sudah dapat melihat dan merasakan lapangan pekerjaan yang ada di Indonesia terutama disekitar mereka sangatlah sempit bahkan dapat dikatakan minim. Apalagi dengan tingkat pendidikan yang relatif rendah. Bagaikan peribahasa mencari jarum ditumpukan jerami. Kesulitan tersebut membuat mereka menetapkan hati dan niat untuk mengadu nasib di luar negeri dengan bekerja seadanya.
Meskipun Kabupaten Gresik merupakan kota industri tapi standar pendidikan untuk pekerjaan di industri-industri tersebut memiliki batasan yang cukup tinggi. Hampir seluruh industri yang ada di Gresik menjadikan lulusan SMA (sekolah menengah atas) sebagai batas minimum untuk merekrut pekerja mereka. Sedangkan di perbatasan Kabupaten Gresik hanya mampu menyekolahkan anak-anak mereka hanya sampai SMP (sekolah menengah pertama) menjadi hal yang mendasari mereka untuk lebih memilih menjadi TKI daripada harus bekerja di Kabupaten Gresik.

Apabila faktor yang mempengaruhi mereka adalah keluarga yang terlebih dahulu menjadi TKI maka, hal tersebut membuktikan bahwa menjadi TKI tidak serta merta mutlak dapat meningkatkan perekonomian keluarga secara signifikan. Tetapi, pengaruh dari keluarga karena tidak ingin keluarganya mengalami kesulitan dalam mencari pekerjaan. Karena masih banyak pemikiran disekitar kita yang menyatakan bahwa tingginya tingkat ekonomi (pendapatan) maka akan semakin dihormati dan 
diagungkan oleh orang yang ada disekitarnya.

Sesungguhnya menjadi TKI bukanlah hal mutlak yang dapat menjadikan mereka untuk lebih baik dari segi finansial, karena apabila individu (TKI) tersebut tidak memiliki pengaturan keuangan yang baik maka tidak ada saving (tabungan) untuk keluarga yang ditinggalkan dan apabila hal tersebut terjadi maka mereka tidak dapat meningkatkan perekonomian keluarga dan mengangkat derajat keluarganya.

Bahkan cara pengaturan keuangan mereka dapat dikatakan sangatlah ekstrim, karena mereka mengakui untuk makan sehari-hari tidaklah teratur, dalam sehari makan hanya 1-2 kali saja. Bahkan ada yang sampai rela berpuasa demi dapat menyisihkan uang mereka untuk keluarga yang ditinggalkan. Hal tersebut terjadi karena banyaknya biaya yang dikeluarkan oleh para TKI. Dari biaya transportasi, dokumen (legalitas), sewa tempat tinggal, dan lain-lain.

Biaya sewa transportasi menjadi biaya yang cukup besar karena pemukiman yang mereka tinggali jauh dari tempat kerja. Jadi di salah satu Negara (Malaysia) memiliki aturan bahwa untuk pemukiman TKI harus ditentukan oleh Negara dan hal tersebut jauh dari lokasi kerja. Apabila untuk legalitas maka mereka harus membayar setiap tahunnya, apabila mereka tidak melakukan perijinan maka resiko yang dihadapi adalah tertangkap oleh pihak berwajib saat terjadi razia, dan fenomena tersebut tidak sedikit yang mengalaminya.

Status legal maupun ilegal menjadi salah satu penghambat dalam pekerjaan ini. Tidak sedikit para TKI yang berstatus illegal karena kurangnya biaya untuk pengurusannya. Status illegal juga menjadikan resiko yang mereka hadapi bertambah, karena mereka yang illegal (kosongan) harus menghadapi ketakutan tersendiri saat adanya razia dari pihak berwajib. Apabila mereka tidak ingin tertangkap maka mereka harus berlari dan bersembunyi, bahkan tempat bersembunyi teraman adalah hutan (hutan kelapa sawit). Mereka harus bertahan tanpa makan dan minum, bahkan apabila butuh makanan harus makan seadanya di dalam hutan. Dapat di bayangkan bagaimana hidup dalam hutan berhari-hari demi keamanan 
mereka dan demi bekerja kembali menjadi TKI.

Resiko kecelakaan kerja juga membayangi para TKI, mereka sangat memahami dengan resiko tersebut tapi tidak menyurutkan keinginan mereka untuk bekerja di negara orang. Resiko kecelakaan kerja akan terasa semakin berat apabila tenaga kerja tersebut tidak memiliki ijin atau ilegal (kosongan). Tetapi bagi TKI yang legal dan mengalami kecelakaan kerja maka negara tempat mereka bekerja akan mengeluarkan biaya perawatan atau sejenis sebagai bentuk asuransi kerja.

Pengaruh lingkungan juga membuat mereka menjadi TKI, karena melihat para saudara, tetangga, maupun teman yang sukses menjadi TKI dengan membuktikan sudah merubah taraf kehidupan dari segi perekonomian mereka. Semua orang ingin kehidupan yang lebih baik dari masa lalunya.

Keadaan masyarakat dengan tingkat pendapatan rendah membuat mereka memilih untuk berhenti sekolah dan memilih untuk bekerja, dengan pilihan kerja di Negara lain yang tidak melihat tingkat pendidikan tetapi mendapat kompensasi yang dapat dikatakan lebih dari negaranya sendiri. Bahkan dengan berbagai resiko yang mungkin harus mereka hadapi. Jadi, semuanya berawal dari rendahnya tingkat pendapatan yang membuat mereka menempuh jalan pintas dengan mengadu nasib di Negara lain.

Mereka harus mencari kerja dinegara lain karena mungkin mereka merasa bahwa di negaranya tidak memiliki ruang untuk dapat bergerak dan berkembang. Hal inilah yang harus diperhatikan oleh pemerintah terutama pemerintah daerah untuk membuka lapangan pekerjaan baru melalui program wirausaha, dengan melakukan pemberdayaan dan pembinaan pada masyarakat yang memiliki pendidikan dan ekonomi rendah. Karena sesungguhnya berwirausaha tidak harus berawal dari modal secara finansial.

\section{KESIMPULAN}

Berdasarkan hasil penelitian dan pembahasan pada bab sebelumnya, maka dapat disimpulkan sebagai berikut:

1. Banyaknya Masyarakat Indonesia yang menjadi TKI tidak menghiraukan faktor legalitas yang berdampak pada banyak hal, seperti asuransi kerja, keamanan dan kenyamanan 
saat hidup saat berada di negara yang mereka tinggali, serta kepemilikan akan properti di negara tersebut, sesungguhnya apabila TKI tersebut legal maka akan mudah pula untuk berganti status kewarganegaraan.

2. Faktor yang mempengaruhi masyarakat Indonesia khususnya masyarakat Kecamatan Panceng untuk menjadi tenaga kerja Indonesia di luar negeri ada berbagai hal. Diantaranya faktor ekonomi (finansial), sempitnya lahan pekerjaan di Indonesia, rendahnya tingkat pendidikan di wilayah pedesaan, dan juga pengaruh lingkungannya.

3. Menjadi TKI tidak menjadi jaminan untuk merubah kehidupan mereka menjadi lebih baik, karena untuk menjadi lebih baik tergantung kepada individu yang menjalaninya. Karena setiap kehidupan manusia memiliki risiko dan ujiannya masing-masing tetapi tidak semua manusia dapat mengahadapi dan berlaku bijaksana dalam mengahadapinya.

\section{DAFTAR PUSTAKA}

Depnaker, 1994. Pedoman Penempatan Kerja Ke
Luar Negeri, Jakarta:

Dirjen Pembinaan

Penempatan Tenga

Kerja.

Kreitner, Robert dan Angelo

Kinicki. 2014. Perilaku

Organisasi:

Organizational

Behavior, Jakarta:

Salemba Empat.

Moleong, Lexy J. 2006.

Metodologi Penelitian

Kualitatif, Ed. 22. PT.

Remaja Rosdakarya.

Bandung.

Pusat Pembinaan dan

Pengembangan

Bahasa. 1978.

Pedoman Penulisan

Laporan Penelitian. Jakarta: Depdikbud.

Sinungan, $\quad$ M. 2008 . Produktivitas Apa dan Bagaimana. Bumi Aksara, Jakarta.

Sugiyono. 2008. Methode Penelitian Kuantitatif, Kualitatif, $R$ dan $D$. Alfabeta. Bandung. 